\title{
The role of museum institutions in relation to research on Sámi culture, history, and society in Norway until the post World War II years
}

\section{DikKa STORM}

\begin{abstract}
This article examines the roles of two Norwegian museums; the Ethnographic Museum in Oslo and Tromsø Museum in Northern Norway, in relation to the production of Sami research from the end of the nineteenth century until the Post World War II years. By emphasising the academic development of Ole Solberg, Just Qvigstad, Gutorm Gjessing, Knut Kolsrud and Ørnulv Vorren and the development of professional networks, the article calls attention to the establishment of a research strategy in 1913, the establishment of the Institute of Comparative Research in 1923, and the effects of these for studies of Sámi culture and society. Moreover, the article argues that the ethnographer Ørnulv Vorren and Tromsø Museum became important contributors to the advancement of Sámi research and the bolstering of the Sámi ethno-political movement. ${ }^{1}$
\end{abstract}

Keywords: History of ethnography, Norway, Ethnographic Museum in Oslo, Tromsø Museum, Institute of Comparative Research of Human Culture, studies of Sámi cultures.

In this article, I will illuminate different perspectives related to research on Sámi culture, history, and society at the Ethnographic Museum in Oslo, and what would become the ethnographic department at Tromsø Museum from the end of the nineteenth century until the post-World War II years. Using a biographical approach, where the importance of individual academic development in relation to the development of networks of professional groups is taken into consideration, I focus on a particular strategy of scientific research on the Sámi. I specifically consider the role of Ole Solberg (1879-1946) and his students and recruits, the archaeologist and anthropologist Gutorm Gjessing (1906-1977), and the ethnographer Ørnulv Vorren (1916-2007), but I will also 
shed light on other noteworthy figures in this network. As Solberg, both Gjessing and Vorren were directors of the Ethnographic Museum in Oslo, and/or at Tromsø Museum for more than half a century. By illuminating their manifold approaches, I want to explore how Sámi research was developed in a collaboration between the universities and the ethnographic museums. I am specially interested in how the studies of the Coastal Sámi culture and societies were integrated, in spite of the explicit goal of studying reindeer herding. The concept of the Coastal Sámi included the focus on different groups of the Sea Sámi, the reindeer herding Sámi, the 'Markabygd' Sámi, and a combination of these. ${ }^{2}$ Moreover, the process of the establishment of the Institute of Comparative Research of Human Culture in Kristiania [Oslo] in $1923^{3}$ was a model and an inspiration for studies on Sámi culture and society, which have had a lasting impact until today.

\section{Ole Solberg and the coining of a SÁMI RESEARCH PLAN}

Ole Solberg started his museum career as associate professor (1906-1908) at the Museum of Ethnography in Oslo, and later he became a research fellow in ethnography (1912-1917) at the University of Kristiania. In 1917, he was appointed professor and director at the museum (Gjessing \& Johannessen 1957:42). Solberg's studies of the prehistoric inhabitants of the island of Dálmmat/Kjelmøy in Varanger, was according to the archaeologist Inger Storli (1986:47-48) central to the development of the study of the so-called Sámi Iron Age (1909). Solberg carried out studies of the Sámi in Sweden (1902) and the Hopi in Arizona (19031904) (Solberg 1906; Gjessing 1962:142-145; Klausen 1981a:141-153; Kyllingstad 2008:340).
During a longer stay at the University of Leipzig, he wrote his thesis in ethnography on religious practice among the Hopi Indians (Isachsen 1948:42), with archaeology and anthropology as subsidiary subjects. From 1914 until the 1930s, he continued to do fieldwork in Sámi settled areas such as in Aarporte/Hattfjelldal and Sážžá/Senja, among others (Solberg 1934-1944:3-5). His main goal was to build up the museum as an institution of research and mediation. That implied recruitment of researchers within each field, the accumulation of the different collections, and attending to the everyday tasks of the museum (Gjessing \& Johannessen 1957). Also included, was the building up of the library, as well as publishing. Solberg stimulated his recruits to become coeditors and to publish source material, in addition to their own studies. Solberg was a skilled collector who made use of both a qualitative and systematic approach. $\mathrm{He}$ built up the collections in relation to his own research (Hopi and Sámi), as well as acquired items from other collections from all over the world, as well from indigenous peoples, such as the Inuit (Greenland, Alaska), and the Sámi in Northern Norway (Isachsen 1948:42-43, Gjessing \& Johannessen 1957:45,121, 145-146; Bouquet 1996:47-59). During World War II the Ethnographic Museum, which was located in the center of Oslo, was occupied by the Germans. Solberg sold his own flat, and when his house was confiscated, he lived at the loft of the museum while looking after it and the part of the collections which were not evacuated.

In connection with the upheaval of the Union between Sweden and Norway in 1905, the first case to be settled between the two nations was the disagreement on reindeer herding management and the grazing areas within the two states (Isachsen 1948:45). Solberg's (1928/1913:10-15) approach to the 


\section{THE ROLE OF MUSEUM INSTITUTIONS IN RELATION TO RESEARCH ON SÁMI CULTURE, HISTORY, AND SOCIETY IN NORWAY UNTIL THE POST WORLD WAR II YEARS}

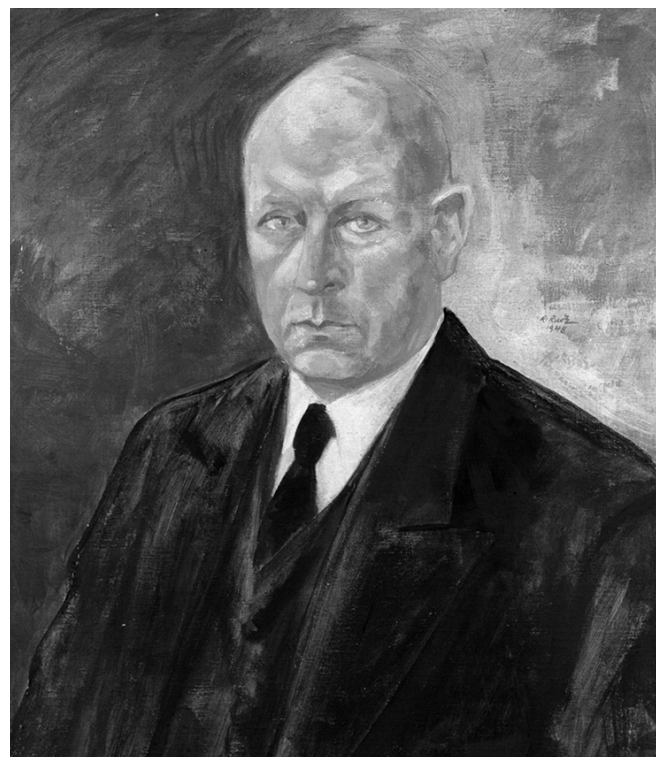

Fig. 1. Ole Solberg (1879-1946), professor of ethnography and director of the Ethnographic Museum in Oslo 1917-1946. Kulturhistorisk museum, Universitetet i Oslo. Painting: Eivind Engebretsen. Photo: Ann Christine Eek.

issue was formulated in the "Memorandum", which became the basis for the development of a research program at the Institute of Comparative Research on Human Culture ten years later (discussed in detail below). The program was based on the question brought about by the "Reindeer grazing commission" and the management of the border-crossing reindeer herding in the northern part of Norway and Sweden (Stang 1928:10-23; Isachsen 1948:45; Storm 2009:13-44). Focusing on reindeer herding, Solberg developed a comprehensive strategy to approach and develop research on Sámi societies, culture, history and language. Research at the Ethnographic Museum followed the themes sketched out in the strategy. In connection to the research on other themes such as language, physical anthropology, and law, among others, they were taken care of by researchers in different disciplines at the university. Solberg played a central role in this process, as he had connections to both the museum and the university and he had profound knowledge of the cultures and history of East Finnmark (Isachsen 1948:40-49; Gjessing \& Johannessen 1957:36-49; Storm 2010:343-345). Inspired by the the German-American anthropologist Franz Boas ${ }^{5}$ (1858-1942), Solberg (in Stang 1928:12) elaborated how the research on the culture of the Arctic People could be executed (Storm 2010:344). He listed ten objectives, or areas, which he found relevant to expand on and concretize relating to the existing sources and the possibilities to engage researchers representing the various disciplines and/or themes (Solberg in Stang 1928:10-15). These objectives, or areas, were listed as follows (here the endonym "Sámi" is used rather than the exonym "Lapps/Lappish", which was dominant at that time and written by Solberg):

1. to shed full light on the activities in connection to the reindeer; herding/ husbandry industry, as an economic basis to focus on the "the real Culture of the Sámi”;

2. Sámi ways of settlement including the nomadic camp and its organisation, also the transition to permanent settlements;

3. the material culture of the Sámi compared to the Scandinavian, Qven, or Russian material expressions;

4. collection of folklore, specimen of music, customs and legal conceptions.

5. studies of the pre-Christian ["old"] religion;

6. linguistic research;

7. research in the early history of the Sámi; 
8. archaeological research within the areas inhabited by the Sámi;

9. physical-anthropological studies:

10. research in psychology. ${ }^{6}$

This rather ambitious program was to be accomplished during a five year period. When the period was over, a solid understanding of the first seven areas was expected. The plan had a holistic perspective and applied a comparative approach to build up knowledge by exploring each theme. The main focus was on reindeer herding and husbandry, which was considered to express the "true" Sámi culture (Solberg 1928:13). The perspectives of Sámi history and prehistory were also to be collected and compared with physical anthropological studies. After Solberg became the director of the Museum of Ethnography in 1917, he withdrew from the process.

\section{JUST QVIGSTAD - FURTHER ELABORATION OF THE PLAN}

Just Qvigstad (1853-1957), a linguist in Sámi and Finnish, folklorist, and former rector at the Teachers College in Tromsø, replaced Solberg. At the time, Qvigstad was continuing his research on North Sámi language, folklore, and placenames as senior research fellow with grants from the government (Hansen 1992). In 1924, at the age of 71, Qvigstad presented his elaborated version of the plan on Sámi cultural research in his introductory lecture at the Institute of Comparative Research on Human Culture (Qvigstad 1925:60-82; Jølle 2004:314). Departing from a comparative perspective on the reindeer Sámi population, Qvigstad (1925:74) characterized the Sea Sámi population and economy, one of the groups of the Coastal Sámi, echoing a diffusionistic perspective on loans of culture: "Only the reindeer herding population have generated a particular culture; the Sea Sámi have lived on loans from the Norwegians". The plan was further elaborated by professor Fredrik Stang (1928:10-23), the leader of the institute. He worked out an even more detailed and updated plan, tying the different perspectives from Solberg and Qvigstad together.

The research on Sámi culture and society is an example which shows the importance of the Institute of Comparative Research on Human Culture as a national research arena. The institute has been thoroughly examined by the historian Jon Røyne Kyllingstad (2008), who analysed its establishment, social responsibility, and objectives as an arena where the researchers could work across diciplinary borders, elaborate transborder knowledge production, and the results of these processes. As most Scandinavian research at the time, the studies at the Institute of Comparative Research on Human Culture and Museum of Ethnography, was also influenced by German research traditions (Kyllingstad 2008:9-10). Topics, theories, and methodologies covering the first half of the twentieth century were changed due to to the influence of the AngloAmerican social science tradition, which became of great interest after World War II. Building up the institute as an institution and arena for the production of knowledge and research of international importance was an intensive process during the 1920s and 1930s. Besides invited international expertise, the visiting researchers mainly represented the University of Oslo and other scientific institutions in the capital. In addition, the strengthening of research at the national level and recruitment was emphasised. From 1927 and onwards, researchers from the rest of the country were encouraged to participate by way of grants (Stang 1930:7). There were several 


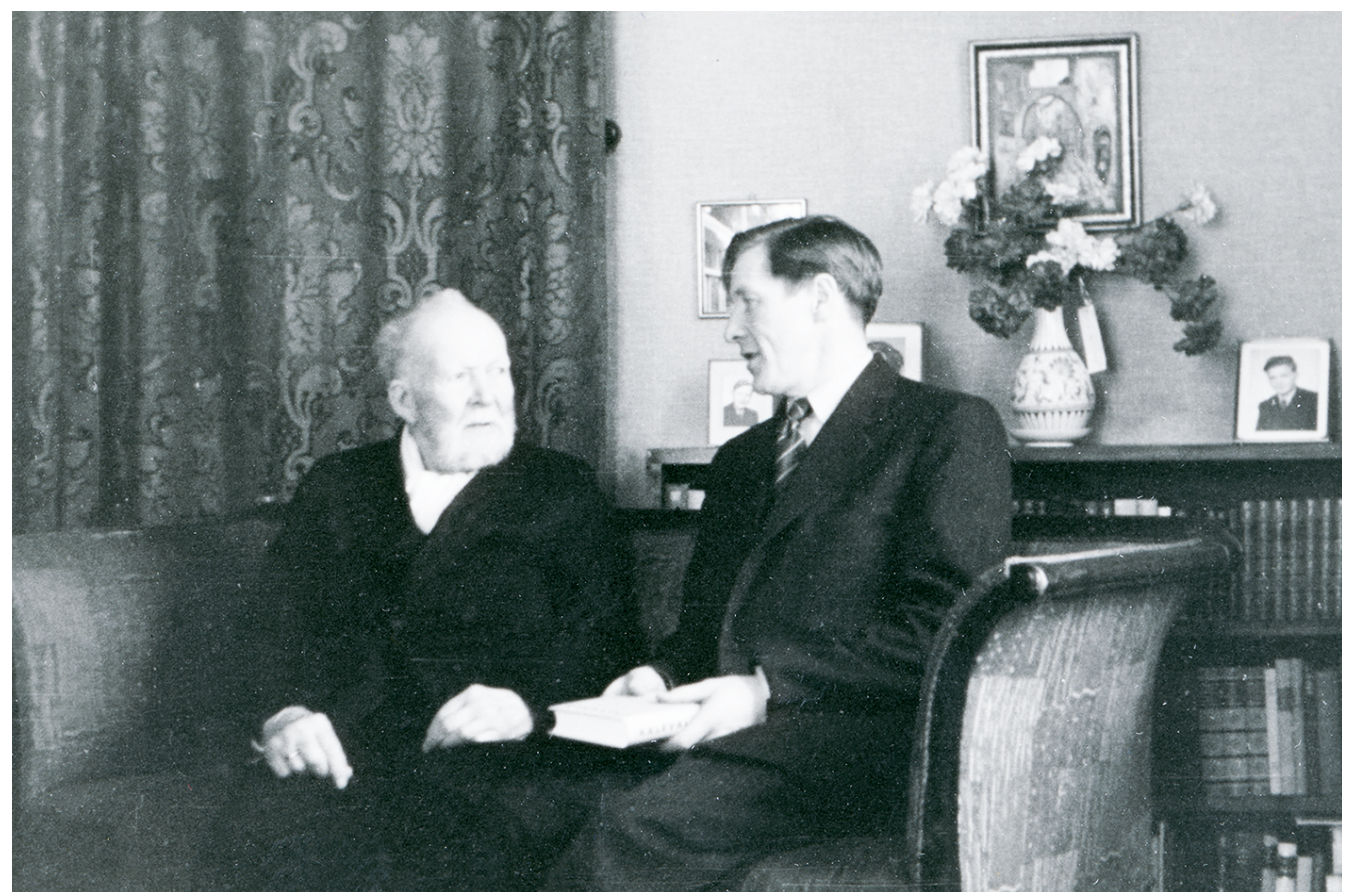

Fig. 2. Just Knud Qvigstad (1853-1957) in conversation with his successor Ørnulv Vorren (1916-2007).

Both were northerners. Qvigststad grew up at Lyngseidet in Troms. Vorren grew up in Neiden in Finnmark. Tromsø University Museum.

visiting researchers from Northern Norway as Qvigstad was from Tromsø. Besides several assignments, Qvigstad had been the manager of the "Lappish [Sámi] collection" of Tromsø Museum while being an unpaid member of the board of the same museum during the period 1884-1934 (Hansen 1992:55). Through Qvigstad's correspondence, there is information about some objects which were gathered for the Sámi collection at the museum. But his collection was mostly in the fields of oral and linguistic information, mainly Sámi language, Sámi placenames, information on sacred places and religious activity, the land use in connection to reindeer herding management, and of folklore.

\section{THE DEVELOPMENT OF A CROSS-} DISCIPLINARY APPROACH

The arena and milieu at the Institue of Comparative Research on Human Culture became important for the development of a cross-disciplinary approach where the research of Sámi culture took place in a multidisciplinary context. In a centennial report, Gutorm Gjessing and Marie Krekling Johannessen (1957:46, 55-57), one of the few female professionals at the time, was responsible for a similar development which took place at the Museum of Ethnography in Oslo. The study of culture of the Arctic peoples was led by professor Solberg as part of a wide approach to ethnographic studies. He put 
special weight on recruitment and research on the Sámi in Norway. In addition to research, Solberg emphasised work in the museum. With his knowledge, experience, qualifications and expertise, Solberg was an active supplier of terms and conditions for the development of research on Sámi society and culture. He remained influential until his death in 1947 (Gjessing \& Johannessen 1957:150-151). The research, collections, mediation and other tasks at the museum were incorporated into a methodical, systematic working strategy. The comprehensive "Memorandum" from 1913 was a basic element of the plan (Stang 1928:1015). ${ }^{8}$ This was later confirmed by, among others, Johannes Falkenberg (1944:54; Gjessing \& Johannessen 1957:56), one of Solberg's recruits and students. In the introduction to his ethnographic study in East Finnmark in the 1930s, he referred to the research strategy as a reason and starting point for the study.

Publication was one of the main tasks of the Museum of Ethnography and was instrumental to the mediation, as well as the building up of a library (Isachsen 1948:45-46; Gjessing \& Johannessen 1957:86-90,151). The museum's publications cover many different areas and disciplines and in particular, consist of publications on Sámi historical sources and historical sources of the Inuit in Kalaalit Nunaat/Greenland. In relation to the research on Sámi culture and society, a series of monographs were published from the period of 1920 to 1941, while the archival series "North Norwegian collections" was published during the period 1932-1947 (Gjessing \& Johannessen 1957:86-90; Storm 2010:345346). In both series, many new studies were published, including studies conducted by the recruits and important source material, which later formed the basis for research on Sámi culture and society. The main focus was on Sámi and Norwegian settlement and economies, as well as the religious situation and social relationships in Northern Norway.

\section{TEACHING AND RECRUITMENT}

The teaching of ethnography was one of the tasks Solberg developed from 1913, and which he emphasised further as professor at the Museum of Ethnography from 1917 (Isachsen 1948:45). The recruitment of students took place in cooperation with the Institute of Geography at the University of Oslo. The teaching took place at both institutions (confirmed by $\varnothing$. Vorren in interviews by author in 1993). The human geographer Fridtjov Isachsen (1906-1979) (1948:41, 45-47) described the cooperation between Solberg and himself. Solberg kept to a formal attitude. At the same time he gave in-depth presentations and induced in the students a good sense of constructive critiscism, style, and form. He was seriously concerned about the students gaining the competence to work at a museum (Gjessing \& Johannessen 1957:42). He pointed out that the tasks of working at a museum were very specialized and demanded certain professional, occupational, and academic qualifications. Above all, however, the work required a long practical education. This demand was not met by choosing an incidental or casual applicant to the position as director, he expressed. Besides Solberg's earlier works, there are only a few publications which can be connected to teaching (Isachsen 1948:45; Gjessing \& Johannessen 1957:44-45).

During the 1930s, there were students within the philological field who combined geography and ethnography with topics of research on Sámi culture and society. In 1938, the teaching was organized in such a way that once a week, professor Isachsen gave lectures 


\section{THE ROLE OF MUSEUM INSTITUTIONS IN RELATION TO RESEARCH ON SÁMI CULTURE, HISTORY, AND SOCIETY IN NORWAY UNTIL THE POST WORLD WAR II YEARS}

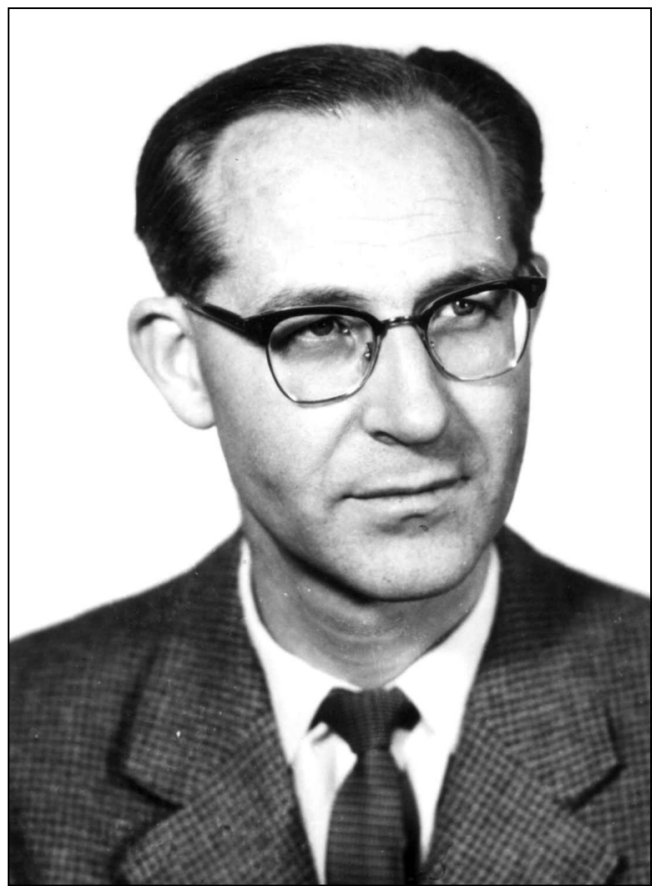

Fig. 3. Knut Kolsrud (1916-1989), one of Solberg's recruits, later curator at Norsk Folkemuseum (Norwegian Museum of Cultural History) and professor of ethnology at the University of Oslo. Norsk Folkemuseum.

at the Domus Academica, in Urbygningen, according to the accounts of Ørnulv Vorren (Storm's interviews of Vorren 1993). ${ }^{9}$ Isachsen is known to have been a brilliant lecturer and very systematic in his introduction of geographical method. It seems there were few lectures and the students were mostly left to fend for themselves, studying in the reading room at the Museum of Ethnography. To take the exam, the candidate had to give a lecture on a chosen theme. The oral examination was conducted by Solberg and Isachsen.

Solberg's knowledge and research on Sámi culture, from prehistory to contemporary times, in Northern Norway, led to the recruitment of

wanted to specialise in Sámi research. Among these students were the already mentioned social anthropologist Johannes Falkenberg (1911-2004) who worked at the Museum of Ethnography in Oslo, as well as Knut Kolsrud (1916-1989) and Ørnulv Vorren. During his lifetime, Falkenberg (1944) combined areas of research, themes, and approaches in contemporary studies of the settlement, material culture, and economy of the Sea Sámi population in East Finnmark (Gjessing 1947:49; Gjessing \& Johannessen 1957:86-90). As a senior researcher at the end of his career at the Norsk Folkemuseum in Oslo, Falkenberg $(1953,1978,1982,1984,1988)$ focused on the South Sámi and their situation, especially with regard to reindeer herding around 1900, a phase that was characterized by radical changes. The study was closely connected to the initial strategy of Solberg. During the 1940s and 1950s, Falkenberg (1948) conducted studies of kinship in Aborigininal societies in North West Australia.

\section{KNUT KOLSRUd AND THE STUDY OF THE CoAstal Sámi}

Another recruit of Solberg was the ethnologist Knut Kolsrud (Gjessing \& Johannessen 1957:57, 86-90; Rasmussen 1990:136-137; Rogan 2002: 323-324). His field of expertise included geography and sociology, which influenced his choices of studies and methods. His main focus was Coastal Sámi settlement and economy in different regions, especially in the counties of Nordland, Troms and Finnmark, from the sixteenth century onward. ${ }^{10}$ Through studies of archival material and fieldwork, he focused on demographic conditions and the material and everyday life in his contemporary 
works. As pointed out by the historian Fredrik W. Thue, the studies of ethnography/ anthropology witnessed a growth after World War II, as did the social sciences in Norway in general, not least inspired by the development at universities in the USA (Thue 1997:155167). From 1946 to 1949, Kolsrud attended lectures in anthropology and held a position as a research assistant at the Chicago Natural History Museum (Rasmussen 1990:136-137; Rogan 2002:323-324). Back in Norway, he became the curator at the Norwegian Folk Museum in Oslo. During the period of 1950 to 1960 , he was also a senior lecturer at the University of Gothenburg. From 1961 to 1986, he was a professor in ethnology at the University of Oslo. He introduced his students to a whole new focus and understanding of the history and culture of the Coastal Sámi. The point of departure was his work on the Coastal Sámi population and economy in Ofuohttal Ofoten in Troms and at Coalmmenuorri/ the sound of Rognsund in Finnmark, as well as other Coastal Sámi settlements (The authors notes from Kolsrud's lectures in Ethnology 1968-1969).

Kolsrud's doctoral thesis on the Coastal Sámi in Ofuohttal Ofoten was completed before 1946, and the next year it was published in the series "North Norwegian collections", edited by Gjessing. Gjessing referred to Kolsrud's thesis as "...methodologically it is primarily historical and the author stresses particularly the demographic evaluation of the material, the ethnographic treatment being secondary" (1947:49). Meanwhile, Kolsrud went to Chicago to study. Because of the war, the master's thesis was published after the doctoral thesis. The master's thesis was a contemporary study of the coastal Sámi population along Coalmmenuorri/ the sound of Rognsund - a sound in West-Finnmark in the south leading

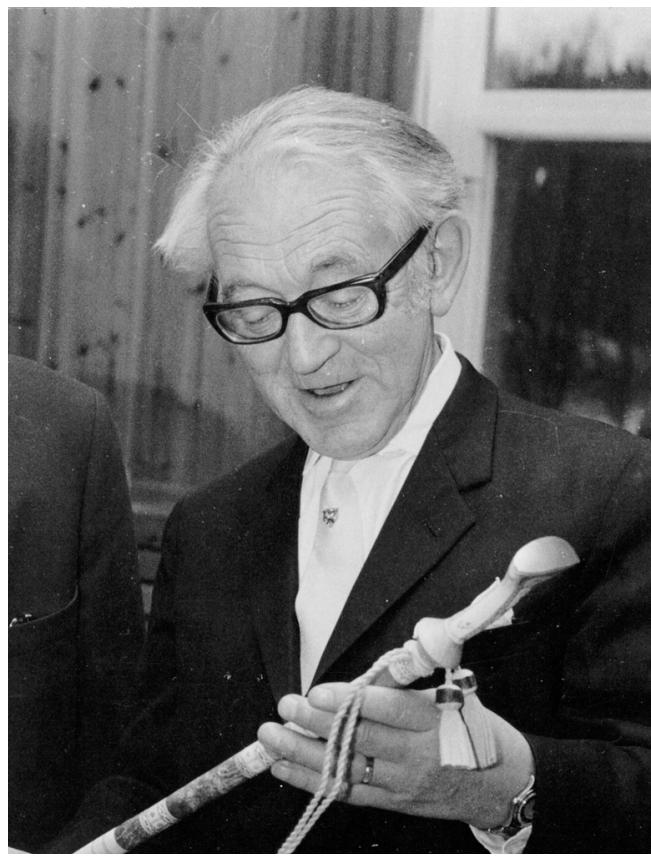

Fig. 4. Guttorm Gjessing (1906-1979) recieving the J.K. Qvigstad prize at Tromsø Museum's centennial in 1972. Tromsø University Museum.

to the Altavuotna/Altafjord. The communities where Kolsrud (1955/1943) conducted fieldwork during the war in 1942, were located on the islands of Stierdná/ Stjernøya and Sievju/ Seiland (Gjessing 1947:49). Sámi handicraft, practice and knowledge had gained new value during the years of World War II due to lack of material goods and food. Kolsrud (1961:56) developed his later study of the Sámi settlements in the fjords of Ofuohtta/ Ofoten as an answer to the comments made by Gjessing (1951) during the dissertation. Through the comparative study of the Sámi settlement in the fjords of Ofuohtta/ Ofoten, Divtasvuodna/ Tysfjord in Nordland and Várjjat/ Varanger in Finnmark, he analyzed their opposite cycles of land use. The settled population was here to be 


\section{THE ROLE OF MUSEUM INSTITUTIONS IN RELATION TO RESEARCH ON SÁMI CULTURE, HISTORY, AND SOCIETY IN NORWAY UNTIL THE POST WORLD WAR II YEARS}

understood as "a processual concept" where the population was located on several dwelling areas throughout a year.

The anthropologist Gutorm Gjessing (1906-1979) was trained as an archaeologist at the University of Oslo where he graduated in 1931. In the late 1920s, he was engaged in different positions, among them, at the Department of Historical and Antiquarian at Tromsø Museum. During the summer seasons he participated in research and fieldwork related to cultural heritage management. From 1936, he contributed as curator, "a professional humanist" as he expressed it himself, and as the manager of the Department of HistoricalAntiquarian, until the spring of 1940 and the outbreak of World War II when he moved to Oslo (Tromsø Museum Årsberetninger; Gjessing 1947:47). While working in Tromsø, Gjessing carried out a series of important projects and studies in North Norwegian archaeology - projects on rockcarving as well as other projects. One project was the systematizing of the different cultural historical collections. The Sámi [Lapp] collection was expanded with detailed drawings and comments. He acquired broad experience, qualifications and skills on research and different tasks at the museum, as well as knowledge of the ethnic composition of the North Norwegian population. According to the cultural anthropologist Arne Martin Klausen (1981b:226), this period gave rise to a permanent interest in 'circumpolar societies' and 'cultural space' - concepts he created, and which became part of the disciplinary vocabulary.

In connection to archaeological findings and excavations, Gjessing became involved in questions about Sámi culture and society. Amongst other topics, he problematized the presentations of the thousand year old textile finding at Skjoldehamn south, at the island of Ánddasuolu/Andøya north in Viester-Álás/ Vesterålen (Gjessing 1938; Storm 1997; Løvlid 2009). Two years later, together with his wife, he co-published mapping and discussion of the sources of the Sámi dress culture in a cultural historical perspective (Gjessing \& Gjessing 1940). ${ }^{11}$ Simultaneously, in connection with the findings of sown boats and burials at the outer coast of Troms (Bårdset, on the NorthKvaløy island) and Nordland (Iksnaššel Øksnes, Skogsøya, Viester-Álás/Vesterålen), these questions were discussed (Gjessing 1938; Gjessing 1941). The excavations reflect the composite ethnic population, and his approach followed the same approach as Solberg at Dállmát/Kjelmøy. But as Gjessing later recognized, and expressed in a retrospect:

Not until 1936, sixty-four years after its foundation, was a professional humanist appointed to the museum, and for several reasons an archaeologist was chosen. He has more than enough tasks to carry out in his own field, without embarking on "Lapp studies" (Gjessing 1947:47).

\section{ØRNULV VORREN, THE ESTABLISHMENT OF A NEW DEPARTMENT AND A NEW RESEARCH PLAN}

Until the mid 1930s, it seems like the emphasis on research of Sámi culture, history, and language was taken care until then by Qvigstad and the theologian Kristian Nissen (1879-1968), as members of the board of the Tromsø Museum, but as Gjessing's comment indicates, the daily operation was in great need of a humanist or social scientist to take on this responsibilty at the museum. At that time, plans were articulated to establish and develop a department with special responsibility for Sámi ethnography. This was realized in 1949 when Ørnulv Vorren was employed as 
curator at the new department - a position he shared while working as a teacher at the Teacher's Training College (Gjessing 1947:47; Aarseth 1994, Storm 2007a,b). From 1952, the position as curator was turned into full-time, and Vorren was appointed head curator at the department in 1959. Moreover, the University of Tromsø was established in 1968 and the Tromsø Museum was incorporated in 1976. Five years before, in 1971, Vorren became a professor in Sámi ethnography (Fulsås 1993). At the beginning of his commitment to the field, Vorren (1950/1951) formulated "a main program for ethnographic research among the Sámi”. It was a comprehensive plan of both regional and thematic studies on the Sámi cultures in Norway. In contrast to previous research on Sámi culture, it was grounded in fieldwork and communication with representatives of Sámi cultural organizations and institutions. Besides the publishing of books and articles, Vorren took a scientific and systematic approach to building up the Sámi ethnographic collection at the museum, and he put great emphasis on mediation by developing the exhibition "The Sámi culture", which was opened in 1973 (see Fonneland, this volume).

\section{GJESSING TURNS TO (HISTORICAL) ANTHROPOLOGY - AND THE COASTAL SÁMI}

After World War II and the death of Ole Solberg, Gjessing was invited to apply for the position of the director of the Museum of Ethnography in Oslo. In 1946, he was appointed director as a professor in cultural anthropology, in spite of his archaelogical background (Klausen 1981b:227). Gjessings change in research orientation toward cultural anthropology was inspired by a visit as a sholarship-holder to the Rockefeller Foundation in the USA 19461947 (Klausen 1981b: 227, 230; 2001:304; Jølle 2004:325). He also expressed a critique of the ideal of objectivity within the social sciences. Within the first years at the museum, Gjessing (1947:54) clarified his view in the introduction of "Norwegian Contributions to Lapp Ethnography". The emphasis was on the study of the Coastal Sámi population and settlements from a combined approach, drawing on archaeological, historical, and ethnographic perspectives:

From the historical-ethnographic point of view, the study of Coast Lapp Culture will be crucial; without it, the question of the origin of Mountain Lapp culture cannot usefully be tackled. The ancient Coast Lapp culture should be approached through a cooperation between the disciplines of archaeology, history, and ethnography: several indications suggest that we have overrated the inland character of the Lapps (Gjessing 1947:54).

The approach was developed further during Gjessings stay at the London School of Economics in 1952 (Gjessing 1954:1, 4). His intense involvement in contemporary Sámi society led to participation in the process of the growing Sámi ethno-political movement, and in the group that formed the Oslo Sámi Sarvi (The Oslo Sámi Association) - the first Sámi political organization. He was appointed a member of the Sámi Commision of 1956, due to his political involvement, but also as professor at the Museum of Ethnography. Throughout the years, he participated in public, as well as, scientific discourses by stating his views and interests to the press, both in popular articles and in scientific publications (Klausen 1981a:155-156; Gjessing 1973). The catalogues at Tromsø Museum demonstrate the interest and systematic approach Gjessing used for 


\section{THE ROLE OF MUSEUM INSTITUTIONS IN RELATION TO RESEARCH ON SÁMI CULTURE,}

HISTORY, AND SOCIETY IN NORWAY UNTIL THE POST WORLD WAR II YEARS

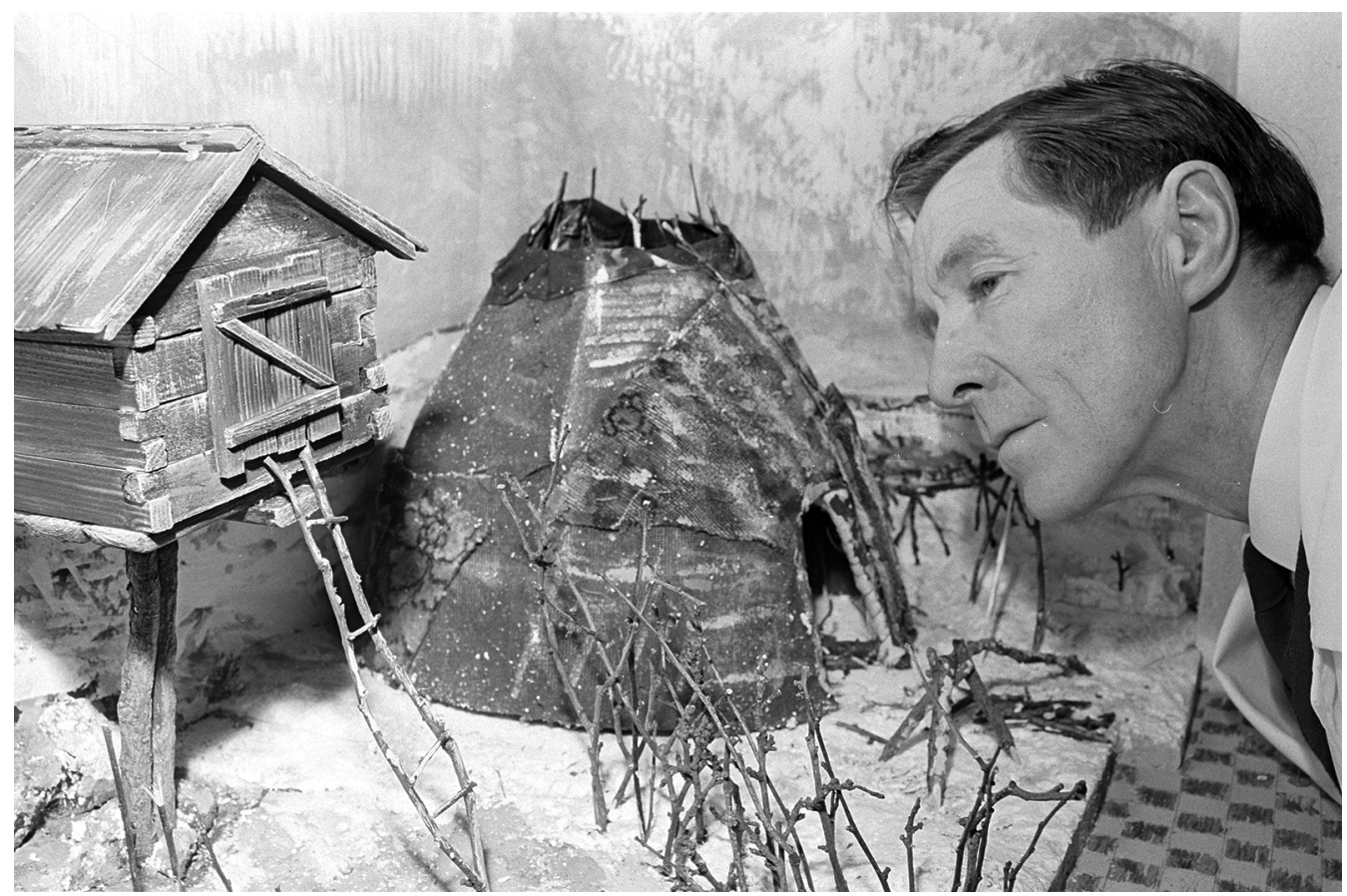

Fig. 5. Ørnulv Vorren inspecting a diorama in the exhibition Samekulturen (1973-). Tromsø University Museum. Photo: Kjell Fjørtoft.

the collections. During work at the Museum of Ethnography, Gjessing took the initative to organize the transfer of the Sámi collection from the museum to Norsk Folkemuseum, also in Oslo, grounded in the perspective that the collection should be part of a larger, national context (Gjessing \& Johannessen 1957:230-231).

\section{CONCLUDING REMARKS: RESEARCH IN THE LONG RUN}

In this article, I have demonstrated the development of research on Sámi culture and societies from the last part of the nineteenth century, until the post World War II period. In particular, I have discussed the roles of two researchers: the archaeologist/ ethnographer/anthropologist Ole Solberg, and the archaeologist and anthropologist Gutorm Gjessing, both of whom established comprehensive research strategies or programs on Sámi culture and society. However, the ethnographer Ørnulv Vorren continued this legacy by followed up with a new research strategy for the next generation of scholars in Northern Norway. With a background in Vorren's comprehensive research program, my objective has been to reflect on and discuss the intentions and content of earlier programs and strategies, as well as illustrate their impacts.

By way of a biographic approach, I have examined the research and work of Solberg and Gjessing, both of whom worked at the 
72 Ethnographic Museum in Oslo. Moreover, apart from international scientific studies, the two researchers carried out substantial studies in Northern Norway. Gjessing worked at the Tromsø Museum for more than a decade. Their work and research led to cooperation with local representatives and to the establishment of the Department of Sámi Ethnography at Tromsø Museum in 1949. Vorren, one of the recruits of Solberg, started to map his future tasks, evidently inspired from his former teacher and colleague. The "Main Program for Research among the Sámi" (Vorren 1950/1951), was an academic platform and key to the future ethnographic research of Sámi culture in combination with Vorren's assignments at the Tromsø Museum.

An analysis of the earlier programs and strategies make visible why the question of the Coastal Sámi were included and realised in the themes of the culture, history and social relations in spite of the earlier, political emphasis on the reindeer herding society during the turn of the century 1900s (see Baglo, this volume). By way of focusing on each researcher, and their perspective on approaches to Sámi research, as well as their engagement in museum tasks, the article sheds light on the great efforts and interest in enlarging the field of study on Sámi culture, history, and society. The focus on Coastal Sámi societies was one of the themes which became a large part of the Sámi Studies during the 1930s, and in the decades to follow. However, spatial and social studies of reindeer herding mangement, as it was stated in the initial reserach program in the beginning of the twentieth century, was followed up by Falkenberg and Vorren. Falkenberg focussed his studies in the south Sámi area, at Røros, while Vorren focussed his spatial studies on the contemporary organization of reindeer herding in Finnmark and Nordland, in addition to studies on the pre-pastoral Sámi society based on the hunting of wild reindeer.

Through his "Memorandum", Solberg summed up a strategy that was useful not only in the political context of reindeer herding management across the Swedish-Norwegian border, but also for the plans of the Institute of Comparative Research on Human Culture. Evidently, the strategy was also to give his research, teaching, recruitment of students, and work at the Ethnographic Museum in Oslo a platform. By way of his research with roots in archaeology and practice in Tromsø and elsewhere, Gjessing continued and developed a broad approach as an anthropologist and professor at the Ethnographic Museum in Oslo. In Tromsø, Qvigstad, the humanist specialized in language, folklore, and religious studies, from 1920 until his death in 1957. With this backdrop, the need for a humanist or social scientist to embark on Sámi Studies is, according to Gjessing, obvious. This was the background and the purpose of the establishment of the "Department of Sámi Ethnography" at the Tromsø Museum in 1949.

\section{Notes}

1. Acknowledgement: I wish to thank the research group of the "SoDi-Sámi" - "The Societal Dimensions of Sámi Research" for the opportunity to present this part of my research, as well as the institutions of The Arctic University Museum of Norway and Centre of Sami Studies, UiT, The Arctic University of Norway.

2. For the term, "Markabygd Sámi" see for example Dikka Storm, "Sámi Natural Resource Exploitation in a Markebygd and Its Significance Today?" Acta Borealia 10.2 (1993): 47-61. 


\section{THE ROLE OF MUSEUM INSTITUTIONS IN RELATION TO RESEARCH ON SÁMI CULTURE, HISTORY, AND SOCIETY IN NORWAY UNTIL THE POST WORLD WAR II YEARS}

3. I have earlier discussed the meaning and role of the institute in relation to research in Sámi culture, history and society (Storm 2010).

4. "The decision of the Board to embark upon a study of the culture of the arctic tribes was based on a memorandum by Professor Solberg, dated Oct. 21, 1913 [..] The Board expressed its agreement with the main points in Professor Solberg's memorandum at a meeting held on Nov.13, 1923; and it appointed a committee to deal with the details of the plan and assume the direction of the work undertaken. Work had since been done in several directions in accordance with the plan thus drawn up". Stang 1928, p.15; Kyllingstad 2008.

5. Franz Boas (1858-1942) born in Westfalen, at that time Preussia. He had his education from Heidelberg, Bonn and Kiel. While working at Berlin Kongelige Etnologiske Museum he began his anthropological studies at Baffin Island, Canada. He emigrated to USA in 1885 , and started as curator at American Museum of Natural History in New York and in 1899 got the position as professor in anthropology at Columbia University; Gjessing 1962:144; Hansen 1992 pp. 57-58; https://snl.no/Franz_Boas.

6. 1. Full belysning av reindriftsvirksomheten, som grunnlag for "dagens ekte samiske (lappiske) kultur"; 2. Samiske bosetningsformer inkludert nomadens leirtype og organisering, samt overgangen til fast bosetning; 3 . Samenes materielle kultur sammenlignet med skandinaviske, kvenske eller russiske materielle uttrykk; 4 . Innsamling av folklore, musikktyper, tradisjon, sedvane og rettsoppfatninger; 5 . Studier av den gamle religionen; 6 . Lingvistisk forskning; 7. Forskning i samenes tidlige historie; 8 . Arkeologiske undersøkelser innen de samiske bosetningsområder; 9. Fysisk-antropologiske studier; 10. Psykologisk forskning (Solberg 1928:10-15).

7. “... Kun renlapperne har frembragt en eiendommelig kultur; sjølapperne har levet på lån
8. https://snl.no/Ole_Martin_Solberg Downloaded 24092015; Solberg participated 1909 as a Norwegian expert in the negotiations about the questions about the reindeer grazing at the court in Copenhagen, Denmark (cf. Wiki O. Solberg; https://no.wikipedia.org/wiki/Ole Martin_Solberg - downloaded 02052016.

9. Domus Academica, urbygningen; Universitetsanlegget ved Karl Johans gate i Oslo stod ferdig i 1852. Bygningen på østsiden av Universitetsplassen kalles til daglig for Urbygningen. Navnet kommer av 'uret' som henger i ett av vinduene, $\mathrm{cf}$. https://www.muv.uio.no/uios-historie/bygninger/ sentrum/urbygningen/

10. The thesis about the Coastal Sámi people in Ofoten was completed before 1946 and later published in the serie "Nordnorske samlinger" (Kolsrud 1947) was finished before 1946 at the Museum of Etnography. The serie was edited by Gjessing, at that time director at the museum (Gjessing 1947:49).

11. Gjessing dated the textiles of the Skjoldehamn finds to the period of the 15th or 16th century. But in resent years some parts of the textiles are dated to about 900 to 1100 after AC.

\section{REFERENCES}

\section{Archival sources}

Ørnulv Vorren 1950/1951. Hovedplan for forskningsarbeidet ved Samisk-etnografisk avd. (Main strategy for research at Department of Sámi Ethnography), Tromsø Museum. Stencil 34 pp. Enclosed five Maps. Archive, Research group of Sámi ethnography, Department of Cultural Science, Tromsø University Museum, UIT.

Dikka Storm \& Ørnulv Vorren 1993 "Interviews of Ørnulv Vorren 1993". Archive, Research group of Sámi ethnography, Department of Cultural Science, Tromsø University Museum, UIT. 


\section{DIKKA STORM}

D. Storm 1968-1969 "Personal notes from the lectures of Knut Kolsrud”, Institute of Ethnology, University of Oslo, Archive, Research group of Sámi ethnography, Department of Cultural Science, Tromsø University Museum, UIT.

\section{Literature}

Bouquet, Mary 1996. Sans og samling...hos Universitetets Etnografiske Museum/ Bringing it All Back Home... to the Oslo University Ethnographic Museum. Oslo: Universitetsforlaget, Universitets etnografiske museum.

Falkenberg, Johannes 1944/1941. "Bosetningen ved indre Laksefjord i Finnmark. Optegnelser fra 1938." Nordnorske samlinger II:2, 54-161.

Falkenberg, Johannes 1948. Et steinaldersfolk $i$ vår tid. Australias innfødte. Oslo: Olaf Norlis Forlag.

Falkenberg, Johannes 1953. "Slektskapssystemet hos Snåsa-samene." In Nils Lid (ed.). Studia Septentrionalia, bind 5, Liber saecularis in honorem J. Qvigstadii: d IV aprilis A.D. MCMLIII editus: Pars II. Oslo: Aschehoug, 69-86.

Falkenberg, Johannes 1978. “Om øremerking av rein hos Røros-samene. Kultur på karrig jord.” In Festskrift til Asbjørn Nesheim. By og bygd 26. Oslo: Norsk folkemuseum, 37-76.

Falkenberg, Johannes 1982. "Sámiske bruksområder og stedsnavn i Rørostraktene”. Åarjel-saemieh/ Samer i sør. Saemien Sijte - Årbok 1982/83, 66-79.

Falkenberg, Johannes 1984. "Fra nomadisme til fast bosetning blandt samene i Røros-traktene (1890 årene - 1940 årene).” Åarjel-saemieh/Samer i sør, Saemien Sijte - Årbok 1984/86:2, 7-28.

Falkenberg, Johannes 1988. "Innføringen av reinbeitedistrikter i Sør-Norge”. Åarjel-saemieh / Samer i sør, Saemien Sijte - Årbok 1988:3, 19-37.

Fulsås, Narve 1993. Universitetet $i$ Tromsø 25 år.

Tromsø: Universitetet i Tromsø.

Gjessing, Gunvor \& Gutorm Gjessing 1940.

Lappedrakten, en skisse av dens opphav. Oslo: Instituttet for sammenlignende kulturforskning. Gjessing, Gutorm 1938. "Skjoldehamndrakten, en senmiddelaldersk nordnorsk mannsdrakt." Viking B II, 27-81.

Gjessing, Gutorm 1941/1935. "Båtfunnene fra Bårset og Øksnes. To nordnorske jernalderfunn.” Tromsø Museums Årshefte 58.

Gjessing, Gutorm 1947. "Norwegian contributions to Lapp ethnography." The Journal of The Royal Anthropological Institute of Great Britain and Ireland 77, 47-60.

Gjessing, Gutorm 1954. Changing Lapps. A Study in Culture Relations in Northernmost Norway. London: Department of Anthropology, The London School of Economics and Political Science. Gjessing, Gutorm 1962. “Ole Martin Solberg”. In Einar Jansen, Jonas Jansen, Øyvind Anker, Gunvald Bøe (eds.). Norsk biografisk leksikon. Bind XIV. Oslo: H. Aschehoug \& Co., 142-145.

Gjessing, Gutorm \& Marie Krekling Johannessen 1957. De hundre år - Universitetets etnografiske museums historie 1857-1957. Oslo: Forenede Trykkerier.

Gjessing, Gutorm \& Kristian Nissen 1951. "Finnefolket i Ofoten. En doktordisputas". Norsk geografisk tidsskrift 13:3-8, 279-313.

Hansen, Lars Ivar 1992. “Just K. Qvigstad's Contribution to the Study of Sámi Culture". Acta Borealia 9:2, 47-68.

Isachsen, Fridtjov 1948. "Minnetale over Professor Dr. O. Solberg". Det norske Videnskaps-Akademi Oslo årbok 1947, 40-49.

Jølle, Harald Dag 2004. “Nordpolens naboer.” In Einar-Arne Drivenes \& Harald Dag Jølle (eds.). Norsk polarhistorie Bind 2. Vitenskapene. Oslo: Gyldendal, 259-327, endnotes 518-522.

Klausen, Arne Martin 1981 (Klausen 1981a). Antropologiens historie. En oversikt over fagets utvikling fra de eldste tider frem til i dag. Oslo: Gyldendal Norsk Forlag.

Klausen, Arne Martin 1981 (Klausen 1981b). "Minnetale over professor Dr. Philos. Gutorm Gjessing”, i Årbok 1980, Det norske Videnskapsakademi, 224-232 


\section{THE ROLE OF MUSEUM INSTITUTIONS IN RELATION TO RESEARCH ON SÁMI CULTURE, HISTORY, AND SOCIETY IN NORWAY UNTIL THE POST WORLD WAR II YEARS}

Klausen, Arne Martin 2001. "Gutorm Gjessing." In J. G. Arntzen (ed.). Norsk Biografisk Leksikon. Bind 3. Oslo: H. Aschehoug A/S, Gyldendal Norsk forlag, Kunnskapsforlaget, 304-305.

Kolsrud, Knut 1947. "Finnefolket i Ofoten." Bidrag til finnenes bygdehistorie og etnografi, Bind 3. Nordnorske samlinger VIII.

Kolsrud, Knut 1955/1943. Sjøfinnane i Rognsund. Ein etterrøknad om busetjing og neringsform i ei samisk bygd $i$ Vestfinnmark. Oslo: Aschehoug.

Kolsrud, Knut 1961. "Sommersete: til problemet om halvnomadisme og seterflytting blant norske sjøsamer." Samiske samlinger 5:1, 1-74.

Kyllingstad, Jon Røyne 2008. "Menneskeåndens universalitet." Instituttet for sammenlignende kulturforskning 1917-1940. Ideene, og institusjonen og forskningen. Dissertation. Faculty of Humanities, University of Oslo.

Løvlid, Dan Halvard 2009. Nye tanker om Skjoldehamnfunnet. Master's thesis. University of Bergen.

Qvigstad, Just 1925. "Institutets opgaver for den lappiske kulturforskning." In Fire innledningsforelesninger holdt 4.-8. september 1924 av Fredrik Stang, Alf Sommerfelt, Knut Liestøl \& Just Qvigstad. Oslo: Instituttet for sammenlignende kulturforskning, H. Aschehoug \& Co, 60-82.

Rasmussen, Holger 1990. Knut Kolsrud 1916-1989. Ethnologia Scandinavica 20, 136-137

Rogan, Bjarne 2002. "Knut Kolsrud." In J. G. Arntzen (ed.). Norsk Biografisk leksikon. Bd. 5. Oslo: Kunnskapsforlaget, Aschehoug \& Gyldendal, 323-324

Samekomiteen av 1956. Innstilling fra Komiteen til å utrede samespørsmål. Oppnevnt 3. august 1956. Kirke- og undervisningsdepartementet.

Solberg, Ole Martin 1906. "Über die Bahos der Hopi. Mit Tafel XXI bis XXIII und 14 Abbildungen." Archiv für Anthropologie 32/504/1/51, 39-76.

Solberg, Ole 1909. "Eisenzeitfunde aus Ostfinmarken. Lappländische studien." Videnskabs-Selskabets skrifter, II. Hist.-Filos. Klasse. 1909. No. 7.
Solberg, Ole 1928. "Memorandum". In Stang, Fredrik 1928. Report on the activities of the Institute for comparative research in human culture in the years 1923-1926. Oslo: Instituttet for sammenlignende kulturforskning, Aschehoug \& Co, 10-15.

Solberg, Ole 1934-1944. "Nogen innledningsord." Nordnorske samlinger 2:1, 3-5.

Stang, Fredrik 1928. Report on the activities of the Institute for comparative research in human culture in the years 1923-1926. Oslo: Instituttet for sammenlignende kulturforskning, H. Aschehoug \& Co (W. Nygaard).

Storli, Inger 1986. "A review of archaeological research on Sami prehistory." Acta Borealia 3:1, 43-64.

Storm, Dikka 1997. "Skjoldehamndrakten - et tekstilfunn fra middelalderen i en bosetningshistorisk sammenheng." In Kvinneforskermaraton $V$. Tromsø: Senter for kvinneforskning og kvinner i forskning, 52-62.

Storm, Dikka 2007a. "Obituary Professor Emeritus Ørnulv Vorren 12 March 1916-7 January 2007." Acta Borealia 23:2, 103-108.

Storm, Dikka 2007b. “Ørnulv Vorren 1916-2007.” Norsk Geografisk Tidsskrift - Norwegian Journal of Geography, 61:4, 218-220.

Strom, Dikka 2009. "Könkämävuomasamenes flytninger til sommerområdene i Troms fylke - en forskningshistorisk oversikt.” In Lars J. Walkeapää, Könkämävuoma-samernas gamla renflyttningar och sommarbosättningar $i$ Troms fylke - $i$ sommerhalvåret från april till september 1900-1944. Tromsø: Tromsø Museum, 13-44

Storm, Dikka 2010. “Rollen til Instituttet for sammenlignende kulturforskning innen samisk forskning - fra tysk forskningstradisjon til fremveksten av samfunnsvitenskapene." Heimen 47:4, 341-356.

Thue, Fredrik W. 1997. Empirisme og demokrati. Norsk samfunnsforskning som etterkrigsprosjekt. Oslo: Universitetsforlaget.

Tromsø Museums Årsberetning 1931-1935, 19351936, 1939-1940,1946 /47-1948-1949. 


\section{DikKa STORM}

76 Aarseth, Bjørn 1994. Ørnulv Vorren - humanistisk forsker og formidler. In Dikka Storm, Nils Jernsletten, Bjørn Aarseth \& Per Kyrre Reymert (eds.). Festskrift til Ørnulv Vorren. Tromsø:

Tromsø Museum, Universitetet i Tromsø, 14-22.

\section{The web}

American Museum of Natural History http://www.amnh.org/about-the-museum/ history/history-1869-1900 - Downloaded 15th of April 2016

Franz Boas

https://snl.no/Franz_Boas - Downloaded 15th of April 2016

http://global.britannica.com/biography/Franz-

Boas by Sol Tax - Downloaded 15th of April 2016

Gutorm Gjessing

https://snl.no/Gutorm_Gjessing - accessed

06122018

https://nbl.snl.no/Gutorm_Gjessing - downloaded 06122018
Ole Solberg

https://no.wikipedia.org/wiki/Ole_Martin_

Solberg - accessed 24092015

https://no.wikipedia.org/wiki/Ole_Martin_

Solberg - downloaded 02052016

https://snl.no/Ole_Martin_Solberg - accessed 24092015

Oslo / Kristiania

Kristiania changed to Oslo from the 1st of January 1925 https://snl.no/Oslo (downloaded 19 February 2016)

\section{Dikka Storm, Curator \\ dikka.storm@uit.no}

The Arctic University Museum of Norway,

UiT The Arctic University of Norway

Postboks 6050 Langnes

N-9037 TROMS $\varnothing$, Norway 